\title{
THE IMPACT OF COVID-19 ON THE INTERNATIONAL BUSINESS ENVIRONMENT: THE INITIATION STAGE
}

\author{
Irina V. Onyusheva \\ Tenzin Thoesam \\ Ann S. Baker
}

Stamford International University, Bangkok, Thailand

This paper is dedicated to one of the most urgent topics nowadays - COVID-19 - and how this virus has affected the international business environment. More specifically, we have studied the impact of COVID-19 on the economy of Thailand and the ASEAN community as well as on the global economy as a whole. In this research we analyze the early stage of this virus spreading in the region on the basis of statistical data obtained from the respected information databases. The Covid-19 pandemic is a stark reminder of the ongoing challenge of emerging and reemerging infectious pathogens. It calls for constant surveillance, prompt diagnostics, and robust research to understand the biology of new organisms and our susceptibilities to them. As practice shows, it takes months and even years until we fully grasp the whole picture of the disease and the global damages it has caused.

Keywords: COVID-19, WHO, global economic impact, Thailand, ASEAN

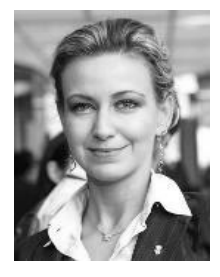

STAMFORD UNIVERSITY Unleash Your Potential

STAMFORD UNIVERSITY unleash Your Potential.

\section{Irina V. Onyusheva}

$\mathrm{PhD}$, Prof. Stamford International University, Bangkok, Thailand.

Research interests: strategic management; ensuring economic competitiveness on microand macro- levels; human capital development; HR management; knowledge economy; project management; management in education.

E-mail: dr.irina.onyusheva@gmail.com

\section{Tenzin Thoesam}

MBA, Stamford International University, Bangkok, Thailand Research interests: international business management, strategic management, change management.

E-mail: tenzin.t@gmail.com

\section{Ann S. Baker}

MBA, Stamford International University, Bangkok, Thailand Research interests: international business management, strategic management, risk management.

E-mail: ann.s.baker@gmail.com 


\section{THE IMPACT OF COVID-19 ON THE INTERNATIONAL}

\section{Introduction}

The latest threat to global health and world economy at the same time is the ongoing pandemic outbreak of the respiratory disease that has been known as Coronavirus Disease 2019 (or Covid-19). Covid-19 was first officially detected back in December 2019 with the epicenter of the first 425 cases reported from the city of Wuhan in Hubei province, China (Fauci et al., 2020). Most of the cases identified at that time had links to the Wuhan seafood market. Identification of the source or intermediate host of the virus was then attempted, focusing on animals normally traded at that market, including snakes, birds and small mammals. However, to date, no specific animal association with the virus has been conclusively identified. The most likely intermediate host candidate is thought to be pangolins as the coronavirus genetic sequences from these animals and from humans infected during the outbreak showed a 99\% match (Prompetchara et al, 2020).

This disease is caused by a novel coronavirus (SARS-CoV-2) that is structurally related to the virus that has caused severe acute respiratory syndrome (SARS) earlier. As in two preceding instances of the coronavirus disease outbreak in the past 18 years, SARS (2002 and 2003) and the Middle East respiratory syndrome (MERS) (2012 to the present), the Covid-19 pandemic outbreak has posed critical challenges for public health, research, medical communities and the global economy (Fauci et al, 2020). As per the Situation Report-92 released by WHO on 21st April, 2020, the total number of cases worldwide has surpassed 2,397,216 cases with the death rate of over 162,956 people.

For most patients, COVID-19 might affect only the lungs because it is mainly a respiratory disease. The primary mode of infection is human-to-human transmission through close contact, which occurs via spraying droplets from an infected individual through their cough or sneeze. Individuals in care facilities, older people and people with medical conditions are at particular risk of disease complications. The mean incubation period of the virus ranges from 2.1 to 11.1 days (on average, 6.4 days), with longer incubation periods of up to 24 days also being reported but still under debate. The WHO experts discussed during the press conference on February 10, 2020 that 24 days reported was either an outlier observation, or could possibly be due to double exposure (Prompetchara et al., 2020).

The efficiency of transmission for any respiratory virus has important implications for containment and mitigation strategies. Current studies indicate an estimated basic reproduction number (R0) of 2.2 which means that, on average, each infected person spreads the infection to another two persons. Until this number falls below 1.0, it is likely that the outbreak will continue to spread (Fauci et al., 2020).

The COVID-19 pandemic has clearly entered a new stage with rapid spread globally, and in order to respond to COVID-19, many countries are using a combination of containment and mitigation activities. The key intention is to delay major surges of patients and to level the demand for hospital beds, while protecting the most vulnerable social groups from infection, including elderly people and those with comorbidities. Activities to accomplish these goals vary and are based on national risk assessment strategies that many times include estimated numbers of patients requiring hospitalisation and availability of hospital beds and ventilation support (Bedford et al., 2020).

Most national response strategies include varying levels of contact tracing and selfisolation or quarantine. The promotion of public health measures including handwashing, respiratory etiquette, social distancing, providing special attention to nursing home facilities, 
postponement or cancellation of large-scale public gatherings are of outmost importance during this crisis (Bedford et al., 2020).

The spread of the virus which has encouraged social distancing has led to the shutdown of financial markets, corporate offices, business and other events. These have led to a decrease in the consumption and investment among consumers, investors and international trade partners (Ozili \& Arun, 2020).

The Covid-19 pandemic has led to unprecedented public concerns about viral transmission via cash. Central banks report a large increase in queries from the media on the safety of using cash. Research in microbiology examines whether pathogenic agents, including viruses, bacteria, fungi and parasites can survive on banknotes and coins. Some viruses, including human flu, can persist on banknotes for hours or days, particularly when diluted in mucus. However, it has been found that non-porous surfaces such as credit and debit cards have higher transfer efficiency, meaning that they can transmit viruses and bacteria more readily. Contactless card payments and online transfers are being recommended (Auer et al., 2020).

The global economy will contract owing to the sudden stops of activity and the resulting income loss in the manufacturing and services sectors across most advanced countries, combined with the adverse effects on financial markets, consumption (through both income and wealth effects), investment confidence, international trade and commodity prices (UNCTAD report, 2020).

For advanced countries' governments, now scrambling to contain the economic impact of the Covid-19 pandemic, the challenge is compounded by persistent fragilities surrounding highly speculative financial positions, in particular, the already unsustainable debt burdens associated with highly leveraged corporate loans. These have been built up over the last decade of "easy money" and against a backdrop of deeply ingrained income inequalities. The avalanche of cheap credits since 2008 has also spilled over to developing countries, creating new financial vulnerabilities and undermining their debt sustainability. They now face distinct pressures and constraints which will make it harder for them to enact effective stimulus without facing binding foreign exchange constraints (UNCTAD Report, 2020).

Lower-income and middle-income countries would require technical and financial support to successfully respond to COVID-19 (Bedford et al., 2020). Furthermore, as these countries do not issue international reserve currencies, they can only obtain them through exports or sales of their own reserves. Exports themselves require significant imports of equipment, intermediate goods, know-how and financial business services. Finally, the financial turmoil from this crisis has already triggered sharp currency devaluations in many developing countries, which makes servicing their debts and paying for vitally necessary imports for their industrial activity far more onerous (UNCTAD Report, 2020).

\section{Topicality of the research problem}

The COVID-19 outbreak is a global pandemic that has resulted in hundreds of countries imposing cross-border and domestic travel restrictions. The widespread travel restrictions across the world are illustrated in Figure 2 which clearly demonstrates that the vast majority of countries have been in lockdown. Limitations on the movement of people, goods and services, containment measures, and border closures have significantly slowed down the global economic activity and international business. With much of the worldwide 


\section{THE IMPACT OF COVID-19 ON THE INTERNATIONAL}

economy being in some form of a lockdown due to the coronavirus pandemic, the world GDP was expected to contract by around 7\% in the first half of 2020 (Oxford Economics, 2020).

The significance of the issue in question is in the speed and scope of the coronavirus impact on businesses and economies across the world. In the current era of globalization, the crisis has highlighted all the downsides of extensive international integration (Legrain, 2020). It has caused significant disruptions in the global supply chains and has resulted in international companies reassessing how they reshape their operations and their supply chains to mitigate such risks in the future. By now, businesses have realized all the risks of relying on complex global supply chains, and many have started planning to relocate at least some of their production elsewhere (Bloomberg, 2020).

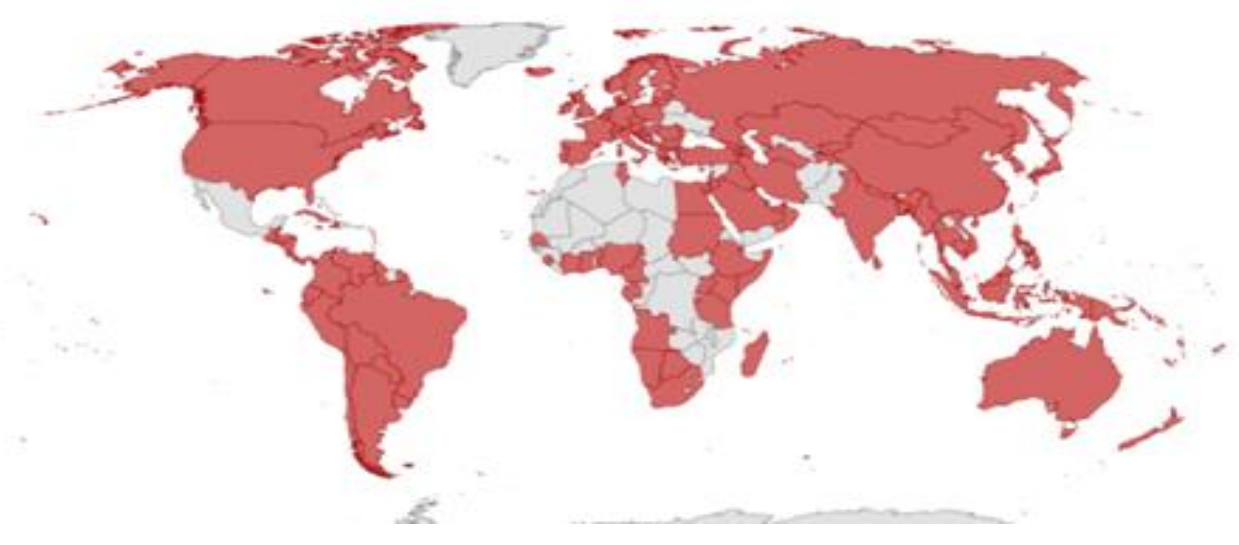

Figure 1 - Countries with travel restrictions due to coronavirus (as of January 2021) (Source: BBC News)

\section{The consequences and impacts on businesses Thailand and ASEAN in general}

The Krungsri Research Intelligence report, published in February 2020, suggested that the situation would be "very severe" in February and March with high mortality rates and transmission ratio. It would later be downgraded to "severe" in April and May, when the mortality rate is expected to drop significantly. The report also stated that since the Chinese account for 30\%-60\% of all tourist arrivals in many countries across Asia, the tourism sector in these countries would be hurt by a sharp drop in tourist arrivals and tourism receipts.

Thailand's tourism sector would be severely hit, even compared to other countries in Asia. It is expected to have tourist arrivals reduced by $30.8 \%$ and $13.1 \%$ in the first two quarters of 2020, respectively. Calculated for the full year, tourist arrivals are expected to drop by $9.0 \mathrm{ppt}$ from the baseline. This drastic drop in tourist arrivals would reduce overall spending, hurt businesses and the overall economy of Thailand (Krungsri Research Intelligence Report, 2020).

Attarangsan (2020) from Kasikorn Bank on the 3rd of March, 2020 published a financial report which estimated Thailand's travel industry to be hit hard due to the falling number of inbound tourists, as Thailand is among the most favorite destinations for Chinese tourists. In February, much before COVID-19 was declared as being pandemic, the 
international passenger arrivals at Suvarnabhumi Airport (approximately 50\% of the total inbound tourists in the country) had tumbled by as much as $51 \%$ YoY (as of February 28).

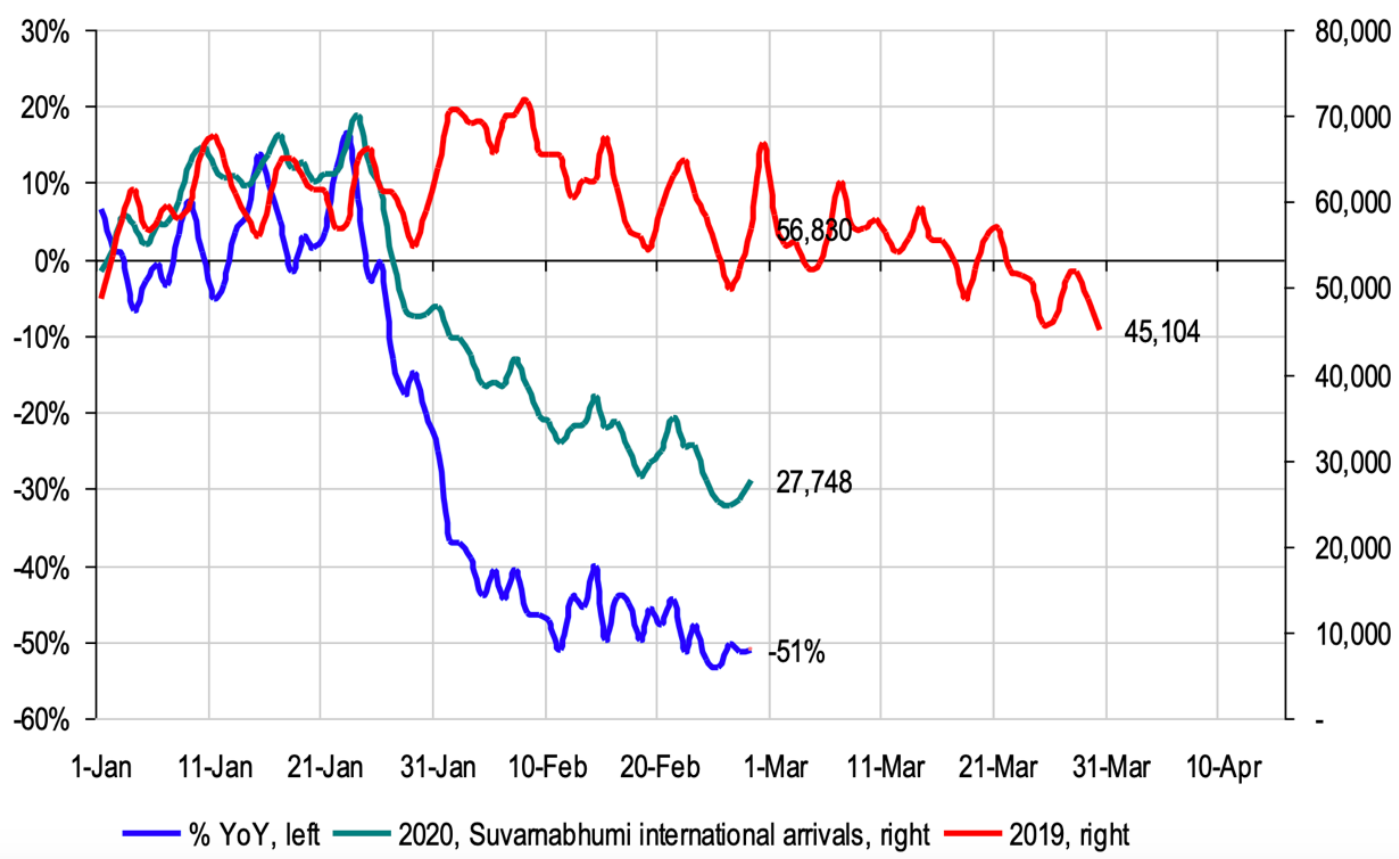

Figure 2 - International arrivals at Suvarnabhumi Airport (Bangkok, Thailand) (Source: Kasikorn Financial Markets Views \& Analysis report, 2020)
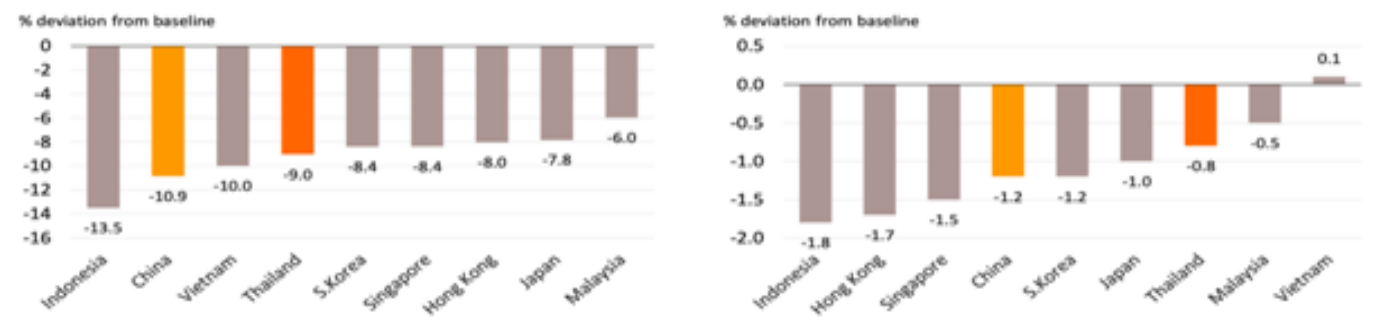

Figure 3 - Impacts on tourist arrivals and exports in Thailand and the selected Asian Countries

(Source: Krungsri Research Intelligence Report, 2020)

Thai economy would be affected by weaker tourism receipts, supply disruptions from China, and negative income effects. Like its neighbors, Thailand's economic growth was forecasted to drop by $0.4 \mathrm{ppt}$ in 2020 . There would be a sharp drop in production which would affect both the backward and forward supply chains. Thai exports were expected to drop by 0.8 ppt from the baseline in 2020, less than the regional peers. Exports to China would be slower than the earlier forecasts stated. But as some Chinese businesses halt their 


\section{THE IMPACT OF COVID-19 ON THE INTERNATIONAL}

production as such, some sectors in Thailand could benefit from the trade diversion, including machinery, electronics, metal and agriculture (Krungsri Research Intelligence Report, 2020).

Thai economy significantly contracted back in 2020 and its headline inflation became negative. There has been a decrease in tourist figures, merchandise exports, the slowdown of trading partner economies and supply chains in 2020. Business and household incomes are being increasingly affected. As a result, domestic demand, both private investments and consumption, are projected to contract even further. The annual average of headline inflation is projected to be negative this year in tandem with the declining energy prices and the contracting economy. A large part of the expenses would be directly related to the expenditures incurred within the healthcare sector. Thai baht has depreciated against trading partner currencies, in particular the major ones, and would likely stay volatile (BOT, 2020).

Table `1 - GDP growth forecasts for 2020

\begin{tabular}{|c|c|c|c|c|c|}
\hline Country & Initi & Forecast & Revised Forec: & & Source \\
\hline $\begin{array}{l}\text { Brunei } \\
\text { Darussalam }\end{array}$ & $1.5 \%$ & Sep 2019 & $2.0 \%^{a}$ & 3 Apr 2020 & ADB \\
\hline Cambodia & $6.8 \%$ & Sep 2019 & $2.3 \%$ & 3 Apr 2020 & ADB \\
\hline Indonesia & $5.3 \%$ & $\begin{array}{l}\text { Official target, } \\
\text { Aug } 2019\end{array}$ & $\begin{array}{r}4.7 \% \text { to } 5.0 \% \\
-0.4 \% \text { to } 2.3 \%\end{array}$ & $\begin{array}{l}4 \text { Mar } 2020 \\
1 \text { Apr } 2020\end{array}$ & Ministry of Finance \\
\hline Lao PDR & $6.2 \%$ & Sep 2019 & $3.5 \%$ & 3 Apr 2020 & ADB \\
\hline Malaysia & $4.8 \%$ & Official target & $\begin{array}{r}3.2 \% \text { to } 4.2 \% \\
-2.0 \% \text { to } 0.5 \% \\
\end{array}$ & $\begin{array}{l}\text { Feb } 2020 \\
3 \text { Apr } 2020\end{array}$ & $\begin{array}{l}\text { Ministry of Finance } \\
\text { Bank Negara Malaysia }\end{array}$ \\
\hline Myanmar & $6.8 \%$ & Sep 2019 & $4.2 \%$ & 3 Apr 2020 & ADB \\
\hline Philippines & $\begin{array}{r}6.5 \% \text { to } \\
7.5 \%\end{array}$ & Official target & $\begin{array}{r}5.5 \% \text { to } 6.5 \% \\
\text { (if outbreak lasts until June) } \\
-0.6 \% \text { to } 4.3 \%\end{array}$ & $\begin{array}{l}\text { Mar } 2020 \\
19 \text { Mar } 2020\end{array}$ & NEDA \\
\hline Singapore & $\begin{array}{r}0.5 \% \text { to } \\
2.5 \%\end{array}$ & Nov 2019 & $\begin{array}{r}-0.5 \% \text { to } 1.5 \% \\
-4 \% \text { to }-1 \%\end{array}$ & $\begin{array}{l}17 \text { Feb } 2020 \\
26 \text { Mar } 2020\end{array}$ & $\begin{array}{l}\text { Ministry of Trade and } \\
\text { Industry }\end{array}$ \\
\hline Thailand & $\begin{array}{r}2.7 \% \text { to } \\
3.7 \%\end{array}$ & Nov 2019 & $1.5 \%$ to $2.5 \%$ & 17 Feb 2020 & $\begin{array}{l}\text { National Economic and } \\
\text { Social Development Board }\end{array}$ \\
\hline Viet Nam & $6.8 \%$ & & $\begin{array}{r}6.27 \% \text { if contained in Q1; } \\
6.09 \% \text { if contained in Q2 } \\
5.96 \%\end{array}$ & $\begin{array}{l}5 \text { Feb } 2020 \\
13 \text { Feb } 2020\end{array}$ & $\begin{array}{l}\text { Ministry of Planning and } \\
\text { Investment }\end{array}$ \\
\hline
\end{tabular}

Regarding the ASEAN in general, China is the ASEAN's biggest external trade partner and investor. In 2018, it had the share of $17.1 \%$ in the ASEAN's total trade, and contributed $6.5 \%$ to the ASEAN's total foreign direct investment (FDI) inflows. The ASEAN's supply chains are heavily integrated with China's manufacturing sector, while the ASEAN tourism sector benefits from the large influx of Chinese tourists. Apart from China, other countries, significantly affected by the outbreak, the US and the Euro Area members, are also among the ASEAN's largest trade and investment partners. Finally, the ASEAN member states (AMS) themselves are also directly affected by the coronavirus outbreak.

The WTO estimated that the world trade is expected to fall by between $13 \%$ and $32 \%$ in 2020, thus exceeding the decline brought on by the latest global financial crisis. Thus, the overall impact on the ASEAN would likely be broad, deep and the impact could vary across the region.

Within the ASEAN group, except for Brunei which expects increased exports of oil and petroleum as new refineries start operations this year, the GDP of other AMS are forecasted to hit negative growth. The immediate disruptions in economic activities across 
the region owing to decline in tourism flows, disruption in air travels and weakening in consumer and business confidence would be the main factors affecting the AMSs' GDPs.

During the onset of the COVID-19 outbreak in Wuhan, the primary concern among the AMS was the possible impact on supply chains because of the temporary closure of the factories in the Hubei province due to lockdowns. Hubei is a major industrial hub, particularly for machineries and electronics. When production there went on a standstill, it created shortages in supply of parts, this forced many supply chains in the region to reduce operations as well. This affected multiple businesses integrated in the supply chains, primarily those within AMS.

As the virus spread rapidly to other countries, including Japan and Korea, it has led to the cancellation of all flights which eventually led to the closure of borders as such. The immediate and direct impact was thus on travel and tourism. These East Asian economies were among the largest sources of tourists within ASEAN, and as travel restrictions further expanded, they led to mass cancellation of bookings within the tourism industry, thus directly affecting thousands of businesses and workers.

Within the ASEAN, even before the outbreak, foreign investments had already became moderate, this was caused by heightened risks from trade tensions. In 2018, foreign equity portfolio stock in the ASEAN dropped by $25.1 \%$ as major investors from the USA and the EU partly pulled out.

The uncertainties brought about by the pandemic also triggered a swift outflow of capital from the ASEAN region, thus causing a deep dive in the markets and rapid depreciation of the exchange rates across the region. Around a fourth of the stock market values in Indonesia, the Philippines, Thailand, and Viet Nam were wiped out. The largest drop was in Viet Nam, where the index fell by $29.3 \%$ from 936.6 at the end of January to 662.5 by the end of March. Moreover, key currencies in the region - Thai Baht, Indonesian Rupiah, and Singapore Dollar, considerably depreciated. The largest depreciation was observed in the Indonesian Rupiah (IDR), which went from IDR13,662 per USD at the end of January to IDR 16,367 at the end of March, a 19.8\% dollar increase.

\section{Global Economic Impact}

The coronavirus outbreak has already brought on major economic disruption. In China, containment efforts have involved quarantines and widespread restrictions on labour mobility and travel, resulting in unplanned delays in restarting the factories after the Lunar New Year holiday and sharp cutbacks in many service sector activities (OECD, 2020). China's economy recorded the first contraction in decades back in the first quarter of 2020. The country's gross domestic product shrank by $6.8 \%$ as compared to the same period of last year, the worst performance since 1992 (Bloomberg, 2020a).

Subsequent outbreaks in other countries have also resulted in similar containment measures. The adverse consequences of such measures in other countries have also been significant. For example, in Thailand, the Bank of Thailand forecasted the economy to shrink by $5.3 \%$ in 2020 , which was the first contraction since the 2008 global financial crisis (Banchongduang, 2020).

Compared to the SARS outbreak in 2003, which similarly originated in China, the coronavirus is projected to have a more considerable negative impact on the global economy (Feuer, 2020). This is because the global economy has become significantly more 


\section{THE IMPACT OF COVID-19 ON THE INTERNATIONAL}

interconnected with the rise of globalization. Furthermore, China today plays a greater role in the global output, trade, tourism, and commodity markets (OECD, 2020).

\section{Disrupted Global Supply Chains}

Globalization and increased business competition have pressured companies to reduce supply chain costs, which has motivated many businesses to pursue strategies such as lean manufacturing, offshoring, and outsourcing (Haren \& Simchi-Levi, 2020). As a result, China became a significant source for foreign direct investments, especially in the manufacturing sectors. China is a major supplier of inputs for manufacturers and retailers all over the world, as its industries are vast sources of components and finished goods. Therefore, as factories stay idle and borders closed, the global pipeline of parts and components became emptier and unable to supply manufacturers and retailers in other parts of the world (Parsons, 2020). For example, Fiat Chrysler Automobiles announced they temporarily stopped production at a car factory in Serbia because it couldn't get parts from China; a sign of how the coronavirus outbreak is creating a domino effect in a straining global supply chain (Foldy, 2020).

China is also a major market for goods and services (Parsons, 2020). Therefore, economies and businesses that depend on China as a customer have also been deeply affected. An example is Mongolia, a country that exports coal to China, which makes up almost half of the export revenues (Stevenson, 2020). Once China and Mongolia's borders became closed, Mongolia's coal exports came to a standstill. Another example is Life Together, a South Korean manufacturer, which earns around 40\% of its sales from China alone (Stevenson, 2020). As logistics slowed down significantly in China, the company's products planned for delivery to China remained idle in storage.

The virus is not only affecting supply chains that involve China. As other parts of the world went under lockdowns, such as the European Union, it has increasingly affected intraEuropean supply chains too (Ortega, 2020).

\section{Reassessing Global Supply Chains to Mitigate Future Risks}

The pandemic has shown the degree of interdependence between economies. This has resulted in some countries looking to reassess their global supply chains and their foreign direct investments.

For example, Bruno Le Maire, the French Finance Minister, said in a statement that France should reduce its dependence on great powers such as China (Ortega, 2020). Japan has also allocated its economic stimulus package to help Japanese manufacturers shift production out of China, as the Coronavirus disrupts supply chains between the major trading partners (Reynolds \& Urabe, 2020). In the tech sector, companies such as Microsoft and Google have looked at Vietnam and Thailand as the countries to move some of their production out of China to (Kharpal, 2020) so that to diversify investments and mitigate risks.

The measures that countries and businesses have taken to move their production bases and redirect their investment illustrates the vast impact COVID-19 has had on international businesses. It also highlights that these impacts are not merely short-term but have long-term impacts on businesses as many reassess their supply and value chains to mitigate such risks in the future. Such mitigation measures will come at a certain cost for many businesses. 
The COVID-19 already has affected the largest businesses. For example, Apple's largest iPhone manufacturing plants are in China, employing over 200,000 local people (McMorrow et al, 2020). When the virus outbreak first started in China, most of Apple's factories were immediately shut down following the government's containment measures. As a result, Apple quickly faced iPhone supply shortages. Apple also has suppliers in Malaysia that make chips and circuit boards, as well as engineers in Germany and other power management chip plants in Italy, Germany, and the United Kingdom (Eadicicco, 2020). As China began to recover, other parts of the world were caught in a domino-effect, constraining supply even further. In February 2020, the global smartphone shipments dropped 38\% yearover-year (Leswing, 2020). For Apple, the shipment of its products dropped from $1.27 \mathrm{mln}$ in February 2019 to 494,000 in February 2020, while sales in China alone dropped by over 50\% (Reuters, 2020).

The demand for Apple's products has also been affected. Stores in China and many parts of the world have closed; those that remain open are operating at reduced hours with low customer traffic (BBC, 2020), as many consumers are limited in their movements around the cities. The economic downturn and uncertainty has also resulted in consumers having less disposable income to spend.

As a result, Apple is working on mitigation plans to move more of its production out of China. The company is now looking to migrate $15 \%$ to $30 \%$ of its production from China to other parts of the South East Asia (Kharpal, 2020). However, such large-scale relocations of production capabilities will certainly take time. They will also be costly and require significant capital for investment. Apple is also playing a big part in corporate social responsibility (CSR) in light of the COVID-19 situation. This global company has donated $10 \mathrm{mln}$ masks for health professionals in the United States and Europe and has also donated around 50 mln yuan to China's efforts to fight the virus (Reuters, 2020).

\section{Conclusion}

The Covid-19 pandemic is a stark reminder of the ongoing challenge of emerging and reemerging infectious pathogens. It calls for constant surveillance, prompt diagnosis, and robust research to understand the basic biology of new organisms and our susceptibilities to them. As practice shows, it has been taking months and even years until we will fully grasp the whole picture of the disease and the global damages it has been causing. The basic health needs and economic security of each and every individual on the Earth has been compromised.

\section{References:}

Attarangsan, S. (2020). Economic Impact of the Spreading Coronavirus. Economics, Facts \& Fallacies. Financial Markets Views \& Analysis. Kasikorn Bank.

Auer, R., Cornelli, G. \& Frost, J. (2020). Covid-19, cash, and the future of payments. Available at: https://www.bis.org/publ/bisbull03.htm.

Banchongduang, S. (2020). BoT predicts 5.3\% GDP dive in 2020. Bangkok Post. Available at: https://www.bangkokpost.com/business/1886495/bot-predicts-5-3-gdp-dive-in-2020. 


\section{THE IMPACT OF COVID-19 ON THE INTERNATIONAL}

BBC (2020). Apple warns Coronavirus will hurt iPhone supplies. BBC News. Available at: https://www.bbc.com/news/business-51539322.

Bedford, J. et al. (2020). COVID-19: towards controlling of a pandemic. WHO Strategic and Technical Advisory Group for Infectious Hazards. The Lancet, 395, 1015-1017.

BOT Press Release (2020). Monetary Policy Committee's Decision 2/2020. Bank of Thailand. Available at: https://www.bot.or.th/English/PressandSpeeches/Press/2020/Pages/n1663.aspx.

Bloomberg (2020). How the Coronavirus is Accelerating Deglobalization. Bloomberg. Available at: https://www.bloomberg.com/news/newsletters/2020-02-29/why-deglobalization-isaccelerating-bloomberg-new-economy.

Bloomberg (2020a). Coronavirus sees China's GDP record first contraction since at least 1992. Fortune. Retrieved from: https://fortune.com/2020/04/16/china-q1-gdp-2020-coronavirus/.

Eadicoco, L. (2020). Apple's supply chain still struggling to return to normal even as China recovers from the pandemic, report says. Business Insider. Available at: https://www.businessinsider.com/coronavirus-apple-supply-chain-iphone-12-production-20203.

Fauci, A. S., Lane, C. \& Redfield, R. R. (2020). Covid-19- Navigating the Uncharted. The New England Journal of Medicine, 382 (13), 1268-1269.

Feuer, W. (2020). Coronavirus: The hit to the global economy will be worse than SARS. CNBC. Available at: https://www.cnbc.com/2020/02/06/coronavirus-the-hit-to-the-global-economywill-be-worse-than-sars.html.

Foldy, B. (2020). Coronavirus pinching car-industry supply chains. Market Watch. Available at: https://www.marketwatch.com/story/coronavirus-pinching-car-industry-supply-chains-2020$02-14$.

Gurman, M. \& Wu, D. (2020). Apple Supply Chain Braces for Disruption From Coronavirus. Bloomberg. Available at: https://www.bloomberg.com/news/articles/2020-01-28/applesupply-chain-braces-for-disruption-from-coronavirus.

Haren, P. \& Simchi-Levi, D. (2020). How Coronavirus Could Impact the Global Supply Chain by Mid-March. Harvard Business Review. Available at: https://hbr.org/2020/02/how-coronaviruscould-impact-the-global-supply-chain-by-mid-march.

Kharpal, A. (2020). Apple, Microsoft, Google look to move production away from China. That's not going to be easy. CNBC. Available at: https://www.cnbc.com/2020/03/05/coronavirus-applemicrosoft-google-look-to-move-production-away-from-china.html.

Krungsri Research Intelligence Report. (2020, March 3). Coronavirus Outbreak: Impact on Thai Economy. Available at: https://www.krungsri.com/bank/getmedia/d706b776-0f5f-4041-b6c971c263fff796/RI_Coronavirus_Outbreak_200211_EN.aspx.

Legrain, P. (2020, March 12). The Coronavirus Is Killing Globalization as We Know It. Foreign Policy. Available at: https://foreignpolicy.com/2020/03/12/coronavirus-killing-globalizationnationalism-protectionism-trump/.

Leswing, K. (2020, March 25). Apple drops after report says company considers delaying next iPhone launch. CNBC. Available at: https://www.cnbc.com/2020/03/25/coronavirus-appledrops-after-report-says-iphone-launch-could-be-delayed.html.

McMorrow, R., Liu, N. \& Hille, K. (2020). Coronavirus hits return to work at Apple's biggest iPhone plant. Available at: https://www.ft.com/content/fc68eaca-521f-11ea-8841482eed0038b1. 
OECD (2020). Coronavirus: The world economy at risk. Organization for Economic Co-operation and Development. Available at: https://www.oecd.org/berlin/publikationen/Interim-EconomicAssessment-2-March-2020.pdf

Ortega, A. (2020). The Deglobalization Virus. The Globalist. Available at: https://www.theglobalist.com/coronavirus-covid19-pandemic-globalization-deglobalizationglobalism/.

Oxford Economics (2020). World Economic Prospects April 2020. Oxford Economics. Available at: https://www.oxfordeconomics.com/.

Ozili, P. \& Arun, T. (2020). Spillover of COVID-19: impact on the Global Economy. Available at: https://www.researchgate.net/publication/340236487_Spillover_of_COVID19_impact_on_the_Global_Economy.

Parsons, T. (2020). How Coronavirus will affect the global supply chain. John Hopkins University. Available at: https://hub.jhu.edu/2020/03/06/covid-19-coronavirus-impacts-global-supplychain/.

Prompetchara, E., Ketloy, C. \& Palaga, T. (2020). Immune Responses in COVID-19 and potential vaccines: Lesson learned from SARS and MERS epidemic. Asian Pacific Journal of Allergy and Immunology, 29 (32), 200-208.

Reynolds, I. \& Urabe, E. (2020). Japan to Fund Firms to Shift Production Out of China. Bloomberg. Available at: https://www.bloomberg.com/news/articles/2020-04-08/japan-to-fund-firms-toshift-production-out-of-china.

Reuters (2020). Apple sells fewer than 500,000 smartphones in China in February amid Coronavirus. Reuters. Available at: https://www.reuters.com/article/us-health-coronavirus-applechina/apple-sells-fewer-than-500000-smartphones-in-china-in-february-amid-coronavirusidUSKBN20W19H.

Stevenson, A. (2020). China Stopped Its Economy to Tackle Coronavirus. Now the World Suffers. The New York Times. Available at: https://www.nytimes.com/2020/03/02/business/economy/china-coronavirus-economy.html.

UNCTAD report. (2020). The COVID-19 Shock to Developing Countries: Towards a "whatever it takes" programme for the two-thirds of the world's population being left behind. United Nations Conference on Trade and Development. Available at: https://unctad.org/en/PublicationsLibrary/gds_tdr2019_update_coronavirus.pdf .

WHO Situation Report-92. (2020). Coronavirus disease 2019 (COVID-19). World Health Organization. Available at: https://www.who.int/docs/default-source/coronaviruse/situationreports/20200421-sitrep-92-covid-19.pdf?sfvrsn=38e6b06d_4.

Paper submitted

Paper accepted for publishing

Paper published online
18 March 2021

28 May 2021

31 July 2021 